\section{US sale of British reagents}

BLOOD-GRoup typing in the United States is likely to be based on monoclonal antibodies, following a deal between Celltech, the British biotechnology company, and Ortho Diagnostic Systems Inc., the Johnson \& Johnson subsidiary which is the largest supplier of bloodtyping reagents in the United States.

Although the British National Health Service has already switched over to Celltech's monoclonals for ABO blood typing, the technology was not simply transferable to Ortho. The US bloodtyping test is differently and more rapidly performed than the British test. Moreover, Ortho's blood-typing reagents, based on antibodies from donated blood, are designed to detect blood group antigens at below the threshold at which British tests operate.

These demands have required a twoyear period of development by Celltech, with support from Ortho. Because the single monoclonal antibodies against blood groups $\mathrm{A}$ and $\mathrm{B}$ developed for use in Britain did not perform adequately in the US tests, Celltech embarked on a worldwide hunt for more appropriate antibodies. Despite screening hundreds of candidates, it failed to find sufficiently sensitive single $\mathrm{A}$ and $\mathrm{B}$ antibodies. So laboratory stands to gain.
Ortho's reagents are each a cocktail of several monoclonals, some of which Celltech have had to buy in from outside. At least one unnamed US academic

There have also been regulatory hurdles to cross. Because traditional blood-typing reagents are blood products, they are licensed by the Office of Biologics of the US Food and Drug Administration. The monoclonals, although derived from cultured cells rather than blood, have been caught by tradition and subjected to the regulations of the Office of Biologics, although other diagnostic monoclonals have passed through other offices.

Material is at present produced in 100litre fermenters, but as Ortho's demand builds up, Celltech plans to switch to its 1,000 -litre fermenter which can yield 100 grams of antibody in a two-week run. If, as expected, monoclonals are eventually used in half of $\mathrm{ABO}$ blood-typing tests worldwide, "a low number of kilograms" of antibody will be needed annually. According to Gerard Fairtlough, chief executive of Celltech, independent estimates put the world market for bloodtyping reagents at $£ 7.5$ million per year. The initial agreement between Celltech and Ortho is for five years, involving

\section{Searle deals blow to Genex}

\section{Washington}

Genex Corporation, which had pinned its hopes for making an early profit on mass production of the chemical L-phenylalanine, the key starting material for the artificial sweetener aspartame, has been dealt a major setback. G. D. Searle, which holds exclusive rights in the United States and most of Europe for the use of aspartame as a sweetener, last week informed Genex that it would be dropping its contract to purchase phenylalanine as from November. Genex is left with an $\$ 18$ million plant that the company says it built on assurance from Searle that it would continue to be a major supplier. The plant, located in Paducah, Kentucky, was completed only last year and it reached full production three months ago.

Genex's president, J. Leslie Glick, acknowledges that the market for other uses of phenylalanine, mainly the production of pharmaceuticals, is "limited", and could not justify keeping the Paducah plant open.

Genex last year had sales of $\$ 20.6$ million, almost all of that from phenylalanine. Research and development contracts, which totalled $\$ 5.7$ million last year, will now once again become the company's major source of revenue. Glick said the company was looking into the possibility of using the Paducah plant for enzyme pro- duction or for joint ventures. Only 25 per cent of the facility is now used for phenylalanine production. The company had been reserving the remaining space for expansion in other areas.

Glick says that Genex's loss for 1985 would be less than last year's despite the setback, largely because the high cost of starting up the Paducah plant was included in last year's accounts. Searle refuses to comment on the decision not to renew its contract with Genex. Searle is known to have expanded its own capacity for producing phenylalanine and it also purchases an undisclosed quantity from Ajinomoto in Japan. Genex's process involved an enzyme reaction of cinnamic acid. Ajinomoto (and Searle, which licenses the process from Ajinomoto) uses selected strains of bacteria and fungi that produce large amounts of phenylalanine from sugar.

Searle patents on the use of aspartame expire in the United States in 1992 and in Europe beginning in 1987. Genex's plant is producing about 2,000 metric tons of phenylalanine a year, about two-thirds of Searle's current need, according to independent estimates. It is estimated that by 1987 the demand for phenylalanine will be 5,700 metric tons per year. Searle's sales of aspartame last year were worth a total of $\$ 585$ million. payments of "several million pounds" to Celltech by Ortho.

John Berriman of Celltech sees no obvious competitors. One Canadian and one Swedish company have potentially suitable monoclonals, but not Celltech's ability to produce them in quantity. Celltech also hopes to produce a monoclonal antibody for rhesus blood typing, but because mice do not produce antibodies against the human rhesus antigen, it has not been possible to use standard hybridoma technology. Instead, Celltech hopes to develop a system of producing a monoclonal antibody against $D$ antigen, the main rhesus antigen, in human lymphocytes transformed by Epstein-Barr virus.

Peter Newmark

AIDS

\section{France to screen blood donors}

France could begin testing all blood donors for antibodies to the virus causing AIDS (acquired immune deficiency syndrome) "within a week", and donors may be told the results. This dramatic action to limit the spread of AIDS in France is presaged by the announcement by the Prime Minister, Laurent Fabius, in the National Assembly last week that, "after much reflection", he had decided that a test must be "obligatory".

The tests will be carried out by the blood transfusion service SNTS (Service Nationale de Transfusion Sanguine), which has been evaluating three different commercially available tests. One is French, prepared by the Institut Pasteur and marketed by the drug company Sanofi, and two US - one from Abbott Industries and the other from ElectroNucleonics (distributed in Europe by the Dutch company Organon). All three tests are based on the ELISA technique (enzyme-linked immunosorbent assay) using killed virus. Because of the loss of envelope protein during the preparation, all of them are more sensitive to antibody to the virus inner protein ( $\mathrm{gag}$ ) than to the envelope protein antibodies.

Exactly which test will be selected is not for SNTS to decide, but Fabius spoke favourably last week of the French product, "which could be exported throughout the whole world". SNTS say that tests could begin within a week, although Fabius himself did not announce a date. He did, however, indicate a cost - FF 200 million ( $£ 20$ million) a year.

On the question of informing donors if AIDS antibody is detected, Fabius is not yet convinced. He has asked for a "more detailed" analysis, and has set up a committee of experts to report to him as soon as possible. The tests are necessary, but unnecessary fears should be avoided, he said.

Robert Walgate 